\title{
The Evaluation of the Religious Commitment Inventory for Bulgarian Pomak Households
}

\author{
Nikolaos Satsios $^{1}$, Kostas Karamanis $^{2}$, Aikaterini Galanou ${ }^{2} \&$ Ioannis Sotiropoulos $^{2}$ \\ ${ }^{1}$ Department of Statistics and Actuarial-Financial Mathematics, University of the Aegean, Greece \\ ${ }^{2}$ Department of Accounting and Finance, University of Ioannina, Greece \\ Correspondence: Nikolaos Satsios ${ }^{1}$, Department of Statistics and Actuarial-Financial Mathematics, University of \\ the Aegean, Greece. E-mail: nsatsios@aegean.gr
}

Received: March 29, 2020

Accepted: April 23, 2020

Online Published: May 17, 2020

doi:10.5539/ijbm.v15n6p118

URL: https://doi.org/10.5539/ijbm.v15n6p118

\begin{abstract}
The aim of the research is to evaluate the Religious Commitment Inventory (RCI-10) on a sample of 400 Bulgarian Pomak households across 5 cities. For this purpose, factor analysis was used in order to confirm the factor structure of the religiosity scale. An interesting aspect assumes that the impact of religiosity on the consumer marketing as well as on the social sciences is especially important. Most significantly, this research demonstrates the universality of the religiosity correlation with socio-demographic factors, such as the place of residence, demonstrating the importance of the religiosity level. The results revealed higher levels of religiosity score in cities populated mainly by Muslims, while lower levels score were observed in cities where a Christian community was also present.
\end{abstract}

Keywords: Pomak households, Bulgarian adaptation, religiosity

\section{Introduction}

In a world that is changing, religion plays a crucial role. From a sociological aspect, religion has a social character and, which is not merely based on theological principles, but also on empirical evidence (Riesebrodt \& Rendall, 2010). A basic element for examining the varieties of Muslim religiosity is to find an appropriate measurement instrument. The article focuses on the evaluation of the Bulgarian version of Religious Commitment Inventory-10 for Pomak households, with the aim to assess the factor structure of the scale and to investigate the effect of socio-demographic factors on religiosity score. Religiosity is usually measured by the RCI-10 scale, which was established by Worthington et al. (2003), emerges to measure reliability for religiosity among Christians, Buddhists, Hindus, Muslims, and nonreligious undergraduates, with Cronbach's alpha between from 0.92 to 0.98 (Miller et al., 2013). Moreover for various religious groups the interpersonal and intrapersonal religious commitment is scored from 1 to 5 , on a Likert scale, comprising of 10 items. To extract these data, variation analysis was conducted to help estimate the impact of background characteristics on the religiosity scale while principal components analysis was applied, with the intention to confirm the factor structure of it. The research gives an overview into the relative significance of the various socio-demographic factors that interact with the religious commitment among Pomaks while at the same time examining the reliability and validity of the Bulgarian version of the RCI-10. For collecting the appropriate data of the study the quantitative method was applied and it structured in the following way: Section 2 gives the theoretical framework according to religiosity with the meaning of the impact on consumer behaviour. Section 3 provides the quantitative method and the statistical tools that were used for the factor analysis. Section 4 reports the results and in section 5 presents the conclusions and implications of the findings. In the last section limitations and future suggestions are discussed.

\section{Theoretical Framework}

The religiosity can enhance the importance on levels of culture and socioeconomic aspects (Plouffe \& Tremblay, 2017; Gebauer et al., 2013; Sedikides \& Gebauer, 2010). When a person is defined as being religious, this signifies how his inner system of beliefs and thus corresponding actions are compatible with the religion in question (Kecskes \& Christof, 1993; Kecskes \& Friedrichs, 2012). In cases where these convictions play a central and defining role in almost all aspects of a person's life, then it can describe him as being highly religious 
(Huber, 2009). As far as religious persons were concerned, this trait of their character or personality, did not manifest itself only in terms of what one believed or had experienced, it was present and prevalent in the way they thought and acted in their daily life (Huber, 2009). Inglehart and Norris (2011) maintain that the feeling of personal safety is a dominant factor in one's religious sentiment. In simple terms, being religious provides a safety net from the traumas that a person suffers in his lives, both physical and mental. Even when one chooses not to raise their child with a religious conscience, the broader social environment seems to be what molds the feeling of religiosity in the child at most (Pickel, 2011). According to Duriez and Hutsebaut (2000), suggest that some religious individuals approach religious beliefs in a closed-minded, unreflective and literal manner, thereby rigidly defending themselves against possible intruders and ignoring other religious viewpoints as a meaningful alternative. In contrast, other religious individuals approach belief contents in a more open minded and symbolic way, considering religion as a meaningful but not exclusive framework that provides one's life with a sense of purpose and meaning (Hoare, 2011). Religion as a cultural phenomenon has a significant effect on people's values, habits and attitudes (Belzen, 1999; Mokhlis, 2009). Knowing the different aspects of religiosity gives the opportunities to managers consider new approaches and strategies when exploring consumer behaviours. Thus, they can tailor their marketing strategies and behaviour according to the religious model they are faced with. The impact of religiousness on marketing as well as social sciences has never been considered not insignificant (Guirdham, 2011; Robbins \& Coulter, 2013). Political circumstances, social and financial status and personal environment are all parameters that determine the consumer behaviour (Armstrong \& Kotler, 2016). Even religion, as much as it defines the identity and family relations, can also be considered as a factor that affects purchasing habits, especially when one individual needs specific items that his religion dictates (Lindridge et al., 2011). Precisely this role of religion in one's life, as well as its correlation to one's cultural surroundings, has been underlined by the studies of Essoo \& Dibb (2004). Willer (2006) has extended these findings on a global scale. In this frame of mind, it's easy to perceive how religion can interact with consumerist actions (Sen et al., 2001). There is a gap between the western societies and their eastern counterparts (mainly Muslim) in terms of the effect of religion on both financial and social behaviours (Willer, 2006).

In particular, the Pomak society oscillates between European and Islamic principles, but usually following western life standards (Malkidis \& Kokkas, 2006). Michail (2003) established a similar pattern within the Pomak communities, as well. Europe, as an all-encompassing, all inclusive hub of people from all over, presented itself as an alternative way of life, offering both tolerance and a sense of belonging (Anagnostou, 2003). Specifically, during the era of urbanization and industrialization, there was a shift of focus and attachment, more emphasis was given on the importance of the individual as a unit rather than on the strengthening of family and community ties (Voas, 2009). Family members, consciously or not, define and shape the code of ethics and attitude in general (Cotte \& Wood, 2004). Those relationships within each family result from long-term interaction among its members (Kirchler \& Hoezl, 2017). In the face of inadequate scientific information about the Muslim communities in Bulgaria and other Balkan countries (Gradeva \& Ivanova, 1998; Lozanova et al., 2007) opened a path for researching the Pomak community.

\section{Methodology \& Data}

In the current research the main subjects were the Bulgarian Pomak households that occupy the region and the city of Smolyan and specifically in the cities of Zlatograd, Madan, Rudozem and Velingrad. A sample of 400 Pomak households has been used for the research purpose in the second semester of 2019. The participation was voluntary and anonymous, and everyone who participated gave their formal agreement beforehand. Each individual who took part in this investigation was a Muslim. The adult head of the household was questioned in order to retrieve information for the household. Households in the survey were selected through the snowball sampling technique.

Specifically, the RCI-10 scale consists of ten items, judging the degree to which someone is religiously committed, with 1 meaning "not at all true" and 5 "totally true". This measures one's involvement in religious duties (Rosmarin \& Koenig, 2020). Six items of the scale relate to intrapersonal religious commitment while the other four examine the interpersonal commitment. The scale has proved to be quite accurate in its results as a measure of religious sentiment as far as both Christians (Clements et al., 2015; Worthington et al., 2003) and Muslims (Alaedein, 2015; Hafizi et al., 2016; Jamaludin, 2013) were concerned. The original version of the RCI-10 that was in English was translated into Bulgarian and then the Bulgarian one was translated again into English. The two English versions afterwards compared. The comparison of these translations showed a one factor solution for the Bulgarian version of RCI-10, not similar to the two factor structure of the original English RCI-10 scale. Typical measurements, such as the mean value and standard deviation have also been calculated in the final description. A variation analysis (Anova) was conducted to enhance estimate the impact of 
sociodemographic factors on the religiosity scale. Tukey's test of homogeneity was also computed to determine similar effects. The cronbach's coefficient was used to estimate the accuracy of RCI-10 and the construct validity of the Bulgarian version was assessed by principal component analysis (PCA). A factor was considered important if its eigenvalue was greater than 1. Data analysis was conducted using SPSS version 24.

\section{Results}

Descriptive statistics are summarized in Table 1, presents the mean score and st. deviation on the religiosity scale, in accordance with demographic criteria. Of the 400 individuals who took part in the survey, $179(45 \%)$ were males and $221(55 \%)$ were females, with an age range of $18-85$ years. $(\mathrm{M}=38.4, \mathrm{SD}=13.9)$. Among the 400 participants, $(\mathrm{N}=191,48 \%)$ were married with children. Most of them resided in the city of Smolyan $(\mathrm{N}=185$, $46 \%)$. Concerning their educational level, the majority of the respondents had secondary education $(\mathrm{N}=161$, $40 \%$ ). Regarding employment status, most of the respondents were labourers/workers ( $\mathrm{N}=198,49.5 \%)$. Finally, it emerged that most families owned their place of residence $(\mathrm{N}=285,71 \%)$. Cronbach's alpha of the Bulgarian version of RCI- 10 was 0.952 , thus, the scale consists a reliable tool. The mean score of the whole sample was 25.3 and the $\mathrm{SD}=11.7$.

Table 1. Descriptive statistics of religiosity on demographic factors

\begin{tabular}{lll}
\hline Factors & Level (N) & M (SD) \\
\hline Gender & Male (179) & $25.8(12.3)$ \\
Marital status & Female (221) & $24.9(11.3)$ \\
& Single (127) & $23.8(11.9)$ \\
& Married / without children (29) & $29.6(11.6)$ \\
& Married / with children (191) & $24.8(11.5)$ \\
& Roommate or partner (16) & $25.4(9.1)$ \\
Place of residence & Widowed or divorced (37) & $29.9(12.3)$ \\
& Zlatograd (36) & $21.1(12.5)$ \\
& Smolyan (185) & $25.2(11.2)$ \\
& Madan (76) & $28.5(11.9)$ \\
Educational level & Rudozem (87) & $25.4(11.9)$ \\
& Velingrad (16) & $20.9(11.9)$ \\
& Primary school (24) & $29.9(12.4)$ \\
& Secondary school (161) & $25.2(11.7)$ \\
& High school (89) & $24.1(12.2)$ \\
& College, Technical School or Vocational (33) & $25.6(12.2)$ \\
Housing situation/possession & University / MSc / PhD (93) & $25.5(10.9)$ \\
& Private / or employee (51) & $26.1(11.9)$ \\
Employment status & State employee (33) & $25.6(13.2)$ \\
& Oaborer / worker (198) & $24(11.5)$ \\
& Rent (42) & $27.6(10.7)$ \\
& Self-employee (13) & $29.6(12.3)$ \\
& Retired (39) & $28.3(9.5)$ \\
& Student (21) & $25.9(11.6)$ \\
& Unemployed (30) & $21.3(12.2)$ \\
& Other (15) & $26.2(12)$ \\
& $27.1(8)$ \\
& $22.1(12.2)$ \\
& $22.6(10.7)$ \\
\hline
\end{tabular}

The analysis revealed that place of residence $(F(4,376)=3.151, p=0.014)$ had heavily impacted the religiosity score. Post hoc Tukey's comparison tests showed that Pomaks who lived in Zlatograd and Velingrad had low-level scores than them of Madan (see Table 2). The observed effect is probably explained by the fact that Madan is a city populated mainly by Muslims. Another explanation came from the local religious leaders. Officials from the chief mufti's office (the spiritual authority over all Muslims in Bulgaria) and the regional muftiship in Smolyan argued that religious activity among Muslims in Bulgaria after 1989 was merely the re-emergence of a piety that had flourished in the country before communism. After the end of it, there was a 
resurgence of religiosity and specifically an Islamic revival (Ghodsee, 2010; 2017). According to Ghodsee (2010), a part of the influence coming from conservative religious organizations is associated with certain Arab countries. The aim of such funding is the retraditionalization of the gender norms among those groups. On the contrary, religiosity tends to be lower in cities where a Christian community was also present, as is the case of Zlatograd and Velingrad (Figure 1). A number of factors, such as urban culture, have been influencing the growing closeness between Bulgarian Christians and Bulgarian Muslims by making them work together in the industrial mining enterprise, i.e. "Gorubso" in the city of Zlatograd (Benovska-Sabkova, 2015; Ghodsee, 2010). One more reason for the rapprochement between Muslims and Christians in Zlatograd is also rooted in the local history under socialism: the influence of the socialist atheist policy led to alleviating the alienation between both confessional groups, yet, people among the Bulgarian Muslims became part of the local communist elite under socialism (Ghodsee, 2010). In the period of communism, the main ideology was that the state imposed atheism and the denouncing of capitalism. As a result, the development of any religious belief was discouraged and thwarted.

Table 2. Tukey's homogeneity test for place of residence levels

\begin{tabular}{|c|c|c|c|}
\hline \multirow{2}{*}{ Place of residence } & \multirow{2}{*}{$\mathrm{N}$} & \multicolumn{2}{|c|}{$\underline{\text { Subset for alpha }=0.05}$} \\
\hline & & 1 & 2 \\
\hline Velingrad & 16 & 20.9 & \\
\hline Zlatograd & 36 & 21.1 & \\
\hline Smolyan & 185 & 25.2 & 25.2 \\
\hline Rudozem & 87 & 25.4 & 25.4 \\
\hline Madan & 76 & & 28.5 \\
\hline
\end{tabular}

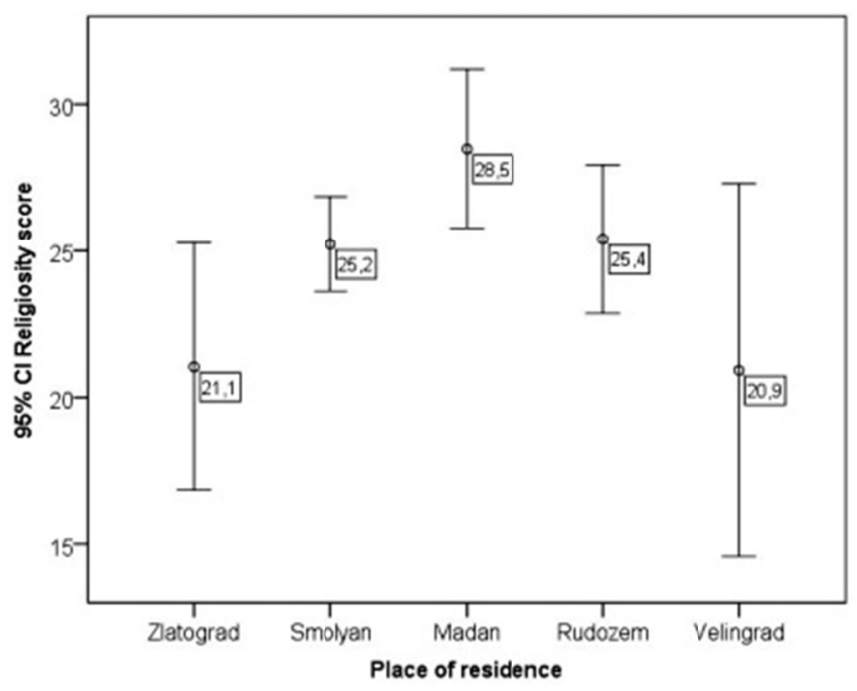

Figure 1. Place of residence effect on religiosity

Principal components analysis (PCA) was applied, with the intention to confirm the factor structure of the religiosity scale. The Kaiser-Meyer-Olkin measure of sampling adequacy was 0.939 , and the Bartlett's test of sphericity was statistically significant [c2(45) $=3896.1, \mathrm{p}<0.001$ ], demonstrating that the sample was adequate for principal components analysis. In contrary to the two factor structure of the original scale of Worthington et al. (2012), PCA suggests a one-factor solution for the Bulgarian RCI-10 version with eigenvalue of 7.02 explaining the $70.2 \%$ of the total variance.

The Table 3 shows the factor loadings, means, and standard deviations for each item, and Cronbach's alpha if the item was deleted. An important additional note is that such large Cronbach's alpha score suggests that a shorter version of the Bulgarian RCI-10 scale could be constructed in the future. 
Table 3. RCI-10 items, factor loadings, descriptive statistics, and Cronbach's alpha if items were deleted

\begin{tabular}{|c|c|c|c|c|}
\hline & Items & $\begin{array}{l}\text { Factor Loadings } \\
\text { Factor } 1\end{array}$ & $\mathrm{M}(\mathrm{SD})$ & $\begin{array}{l}\text { Cronbach's Alpha } \\
\text { if Item Deleted }\end{array}$ \\
\hline 1 & I often read books and magazines about my faith. & 0.797 & $2.7(1.5)$ & 0.949 \\
\hline 2 & I make financial contributions to my religious organization. & 0.642 & $1.9(1.3)$ & 0.955 \\
\hline 3 & I spend time trying to grow in understanding of my faith. & 0.896 & $2.7(1.5)$ & 0.943 \\
\hline 4 & $\begin{array}{l}\text { Religion is especially important to me because it answers many } \\
\text { questions about the meaning of life. }\end{array}$ & 0.847 & $3.1(1.6)$ & 0.946 \\
\hline 5 & My religious beliefs lie behind my whole approach to life. & 0.906 & $2.8(1.5)$ & 0.943 \\
\hline 6 & I enjoy spending time with others of my religious affiliation. & 0.877 & $2.8(1.4)$ & 0.945 \\
\hline 7 & Religious beliefs influence all my dealings in life. & 0.909 & $2.6(1.4)$ & 0.943 \\
\hline 8 & $\begin{array}{l}\text { It is important to me to spend periods of time in private religious } \\
\text { thought and reflection. }\end{array}$ & 0.903 & $2.5(1.4)$ & 0.943 \\
\hline 9 & I enjoy working in the activities of my religious affiliation. & 0.878 & $2.4(1.3)$ & 0.945 \\
\hline \multirow[t]{3}{*}{10} & $\begin{array}{l}\text { I keep well informed about my local religious group and have } \\
\text { some influence in its decisions. }\end{array}$ & 0.670 & $2.1(1.2)$ & 0.954 \\
\hline & Eigenvalue & 7.018 & & \\
\hline & $\%$ of Variance & $70.183 \%$ & & \\
\hline
\end{tabular}

\section{Conclusion \& Implications}

The current research investigated the factor structure of the Religious Commitment Inventory (RCI-10) with socio-demographic factors for Bulgarian Pomak households. The research findings revealed that comparing the two versions of RCI-10, the Bulgarian version was more consistent internally than the English one. There's no confirmed verification for the two factor solution of RCI-10 Bulgarian version. Instead, a one factor solution has emerged, indicating that few discrepancies were found between interpersonal and intrapersonal religious commitment among the Bulgarian Pomaks. Specifically, the Bulgarian RCI-10 version emerged as both valid and reliable in terms of estimating the religious factor. It was found that place of residence was a significant factor affecting religiosity. The finding seems to oppose previous research (Worthington et al., 2003) where little differences were established with the socio-demographic characteristics. Still, it is in accordance with the religiosity profile of Greek Pomaks, where place of residence was also proved to be a significant variable (Satsios, 2016). As an interesting point, in both countries the religiosity was larger in cities populated mainly by Muslims, while it was lower in cities where a Christian community was also presented. This fact becoming from a number of factors, such as urban culture, that have been influencing the growing closeness between the Bulgarian Christians and the Bulgarian Muslims. Specifically, the expansion of public urban spaces, owed to socialism, made the coexistence of Christians and Muslims in confessionally homogeneous neighbourhoods, such as Zlatograd, possible (Benovska-Sabkova, 2015). The cause that they were at work together, meaning the industrial mining, contributed to the reinforcement of their proximity. In addition, the communist regime improved the situation of women in the community, by providing them with paid jobs, a fact that offered them a greater sense of independence. The ban on religion rendered the question of gender roles within religious and ethnic minorities "unnecessary", thus, leaving it unexplored until the fall of socialism in 1989 (Fotev, 2001; Stoilova, 2012). These explanations help interpret the lower scores of religiosity for Pomaks who lived in Zlatograd and Velingrad. In contrast, it was found that the religiosity was higher in Madan because it was populated mainly by Muslims and according to mufti's office before communism and after the end of it, there was a resurgence of religiosity, even an Islamic revival (Ghodsee, 2010). Furthermore, a part of the influence coming from conservative religious organizations was found to be associated with certain Arab countries (Ghodsee, 2010). In particular, religion as a cultural element influences the customer's perceptions and attitudes (Imtiaz et al., 2016). These conclusions can be helpful to those in managerial positions who deal with marketing techniques, especially as far as conservative minority groups are concerned. Being aware of the religious habits of one's client, gives the manager an advantage in terms of what he will offer and how he will promote products (e.g. price of the products). Thus, as a cultural parameter, religion becomes a great indicator of consumer behaviour.

\section{Limitations \& Future Directions}

As a limitation, it should be noted that this research is taking only the religiosity scale, thus, it could use other cultural or psychological scales (e.g. SCL-90-R). Another limitation is the social desirability bias when 
responders tended to answer in a way that will be viewed favourably by others. Future studies can include the impact of religiosity with RCI-10 scale on purchasing attitudes and intentions. Furthermore, extensive research in other countries would be highly recommended to identify particular groups within the broad religious denominations (Shiite or Sunni Muslims). Therefore, it would probably be of benefit to make comparisons among various Muslim communities.

\section{References}

Alaedein, J. (2015). Religious Commitment and Psychological well-being: Forgiveness as a Mediator. European Scientific Journal, 11(5), 1857-7881.

Anagnostou, D. (2003). Minorities and the Nation-State in 20th Century Greece. Journal of Southern Europe and the Balkans, 5(3), 381-386.

Armstrong, G., \& Kotler, P. (2016). Marketing: An Introduction (13th ed.). UK: Pearson Education.

Belzen, J. A. (1999). The Cultural Psychological Approach to Religion: Contemporary Debates on the Object of the Discipline. Theory \& Psychology, 9(2), 229-255.

Benovska-Sabkova, M. (2015). Urban Culture, Religious Conversion, and Crossing Ethnic Fluidity among the Bulgarian Muslims (Pomaks). Glasnik Etnografskog Instituta SANU, 63(1), 49-71.

Clements, A. D., Fletcher, T. R., Cyphers, N. A., Ermakova, A. V., \& Bailey, B. (2015). RSAS-3: Validation of a very brief measure of Religious Commitment for use in health research. Journal of Religion and Health, 54(1), 134-152.

Cotte, J., \& Wood, S. L. (2004). Families and Innovative Consumer Behavior: A Triadic Analysis of Sibling and Parental Influence. Journal of Consumer Research, 31(1), 78-86.

Duriez, B., \& Hutsebaut, D. (2000). The Relation between Religion and Racism: The role of post-critical beliefs. Mental Health, Religion \& Culture, 3(1), 85-102,

Essoo, N., \& Dibb, S. (2004). Religious Influences on Shopping Behaviour: An Exploratory Study. Journal of Marketing Management, 20(8), 683-712.

Fotev, G. (2001). Светът на Селските Жени [The World of the Rural Areas Women]. Sofia: LIK.

Gebauer, J. E., Nehrlich, A. D., Sedikides, C., \& Neberich, W. (2013). The Psychological Benefits of Income are Contingent on Individual-Level and Culture-level Religiosity. Social Psychological and Personality Science, 4(5), 569-578.

Ghodsee, K. (2010). Muslim lives in Eastern Europe: Gender, ethnicity, and the transformation of Islam in post-socialist Bulgaria. NJ: Princeton University Press.

Ghodsee, K. (2017). Red Hangover: Legacies of Twentieth-Century Communism, UK, London: Duke University Press Books.

Gradeva, R., \& Ivanova, S. (1998). Vavedenie: Izsledvane na Istoriata i Savremenoto Sastoianie na Miusiulmanskata Kultura po Balgarskite Zemi. In Gradeva, R. \& Ivanova, S. (Eds.), Miusiulmanskata Kultura po Balgarskite Zemi (Vol. 2, pp. 9-53).

Guirdham, M. (2011). Communicating Across Cultures at Work (3rd ed.). UK: Palgrave Macmillan.

Hafizi, S., Tabatabaei, D., Memari, A. H., Rahmani, A., \& Arbabi, M. (2016). Religious Commitment Inventory 10: Psychometric Properties of the Farsi Version in Assessing Substance Abusers. International Journal of High Risk Behaviours and Addiction, 6(3), 151-159.

Hoare, C. (2011). The Oxford Handbook of Reciprocal Adult Development and Learning (Oxford Library of Psychology) (2nd ed.). New York: Oxford University Press.

Huber, S. (2009). Religion Monitor 2008: Structuring Principles, Operational Constructs, Interpretive Strategies. In Bertelsmann S. (Eds.), What the World Believes: Analysis and Commentary on the Religion Monitor 2008 (pp. 17-51).

Imtiaz, A., Wajeeha, A., \& Muhammad, A. (2016). Students' Dependence on Smartphones and its Effect on Purchasing Behaviour. South Asian Journal of Global Business Research, 5(2), 285-302.

Inglehart, R., \& Norris, P. (2011). Sacred and Secular, Religion and Politics Worldwide (2nd ed.). Publisher: Cambridge University Press.

Jamaludin, N. (2013). Religion and Individual Investment Choice Decision: The Case of Malaysia. International 
Journal of Business and Social Science, 4(1), 104-113.

Kecskes, R., \& Christof, W. (1993). Christliche Religiosität: Konzepte, Indikatoren, Messinstrumente. Kölner Zeitschrift für Soziologie und Sozialpsychologie, 45(2), 270-287.

Kecskes, R., \& Friedrichs, J. (2012), Gentrification: Theorie und Forschungsergebnisse (German Edition). Germany, Opladen: VS Verlag für Sozialwissenschaften.

Kirchler, E., \& Hoelzl, E. (2017). Economic Psychology: An Introduction. UK: Cambridge University Press.

Lindridge, A., Ali, H. Lucas, M., \& Francis, G. (2011). Understanding Marketing and Financial Information. UK: The Open University.

Lozanova, G., Alexiev, B., Nazarska, G., Troeva-Grigorova, E., \& Kyurkchieva, I. (2007). Regions, Minorities and European Policies: A State of the Art Report on Muslim Minorities (Turks and Pomaks). In Central South Planning Region (Bulgaria). International Centre for Minority Studies and Intercultural Relations (IMIR), Report European Commission. Retrieved from https://tinyurl.com/yax2hk48

Malkidis, Th., \& Kokkas, N. (2006). Transformations of the Collective Identity of Pomaks. Xanthi: Publications Spanidis.

Michail, D. (2003). From 'Locality' to 'European Identity': Shifting Identities among the Pomak Minority in Greece. Ethnologia Balkanica, 7, 140-157.

Miller, W. A., Shepperd, J. A., \& McCullough, M. E. (2013). Evaluating the Religious Commitment Inventory for Adolescents. Psychology of Religion and Spirituality, 5(4), 242-251.

Mokhlis, S. (2009). Relevancy and Measurement of Religiosity in Consumer Behaviour Research. International Business Research, 2(3), 75-84.

Pickel, G. (2011). Contextual Secularization. Theoretical Thoughts and Empirical Implications. Religion and Society in Central and Eastern Europe, 4(1), 3-20.

Plouffe, R. A., \& Tremblay, P. F. (2017). The Effect of Income on Life Satisfaction: Does Religiosity Play a Role? Personality and Individual Differences, 109, 67-71.

Riesebrodt, M., \& Rendall, S. (2010). The Promise of Salvation: A Theory of Religion, Publisher: University of Chicago Press.

Robbins, S., \& Coulter, M. (2013). Management (12th ed.). Publisher: Pearson.

Rosmarin, D. H., \& Koenig, H. G. (2020). Handbook of Spirituality, Religion, and Mental Health (2nd ed.). US, California: Academic Press.

Satsios, N. (2016). Evaluating the Greek Version of Religious Commitment Inventory-10 on a Sample of Pomak households. Review of Applied Socio-Economic Research, 12(2), 5-11.

Sedikides, C., \& Gebauer, J. E. (2010). Religiosity as Self-Enhancement: A Meta-Analysis of the Relation between Socially Desirable Responding and Religiosity. Personality and Social Psychology Review, 14(1), 17-36.

Sen, S., Gurhan-Canli, Z., \& Mowitz, V. (2001). Withholding Consumption: A Social Dilemma Perspective on Consumer Boycotts. Journal of Consumer Research, 28(3), 399-417.

Stoilova, R. (2012). Джендър и Стратификаиия: Влиянието на Соииалния пол върху Социалната Стратификаиия в България След 1989 [Gender and Stratification: The Influence of Gender on Social Stratification in Bulgaria after 1989]. Sofia: Siela.

Voas, D. (2009). The Rise and Fall of Fuzzy Fidelity in Europe. European Sociological Review, 25(2), 155-168.

Willer, R. K. (2006). Dispelling the Myth of a Global Consumer Indonesian Consumer Behavior Researched by Means of an Analytical Diagram for Intercultural Marketing with a Case-study of Sunsilk Shampoo for the Veiled Woman, University of Zu Berlin, Berlin.

Worthington, E. L., Jr., Wade, N. G., Hight, T. L., McCullough, M. E., Berry, J. T., Ripley, J. S., Berry, J. W., Schmitt, M. M., \& Bursley, K. H. (2003). The Religious Commitment Inventory-10: Development, Refinement and Validation of a brief Scale for Research and Counselling. Journal of Counselling Psychology, 50(1), 84-96.

Worthington, E. L., Jr., Wade, N. G., Hight, T. L., Ripley, J. S., McCullough, M. E., Berry, J. W., Schmitt, M. M., Berry, J. T., Bursley, K. H., \& O’Conner, L. (2012). The Religious Commitment Inventory-10 (RCI-10). 
Measurement Instrument Database for the Social Science.

\section{Copyrights}

Copyright for this article is retained by the author(s), with first publication rights granted to the journal.

This is an open-access article distributed under the terms and conditions of the Creative Commons Attribution license (http://creativecommons.org/licenses/by/4.0/). 